\title{
Perlindungan Hukum Bagi Pihak yang Beritikad Baik Dalam Perjanjian Jual Beli (Studi Putusan Nomor 15/pdt.G/2018/PN.Sby)
}

\author{
Syifa Miftahuljannah ${ }^{1 *}$, Taun ${ }^{2}$ \\ ${ }^{1,2}$ Fakultas Hukum, Universitas Singaperbangsa Karawang \\ Jalan HS Ronggo Waluyo, Telukjambe Timur, Karawang, Jawa Barat, 41361 \\ *Correspondence email: syifamiftahuljannah@yahoo.com, taun@fh.unsika.ac.id
}

\begin{abstract}
Abstrak. Jual beli adalah kegiatan umum yang dilakukan dalam kehidupan sehari-hari. Transaksi jual beli dianggap telah terjadi apabila para pihak telah mencapai kesepakatan atas barang yang dijual dan harga yang ditawarkan yang kemudian dibakukan ke dalam suatu perjanjian. Namun sering kali dalam pembuatan dan pelaksanaan perjanjian tidak mengindahkan syarat dan asas hukum yang terdapat dalam KUHPer yang seharusnya dijadikan pedoman baik pada saat pembuatan maupun pelaksanaan perjanjian. Salah satu kasus tersebut terdapat dalam Putusan Nomor 15/pdt.G/2018/PN.Sby. Penelitian ini bertujuan untuk mengetahui kriteria dalam menentukan salah satu pihak telah beritikad baik dalam melaksanakan perjanjian jual beli dan perlindungan hukum terhadap pihak yang beritikad baik. Dalam penulisan penelitian ini menggunakan metode hukum normatif yaitu dengan cara mengkaji isi Putusan yang kemudian dianalisis dengan interpretasi undang-undang. Berdasarkan hasil penelitian untuk melihat bahwa salah satu pihak telah beritikad baik adalah dengan dua cara yang pertama secara subyektif atau pada saat negosiasi dan penyusunan kontrak dan obyektif dengan melihat bagaimana ia dapat taat pada isi kontrak perjanjian selama perjanjian dilaksanakan. Perlindungan hukum yang dapat diberikan adalah dengan melakukan penyelesaian sengketa dengan melakukan gugatan hukum baik melalui non litigasi melalui Badan Penyelesaian Sengketa Konsumen dengan segala kewenangannya ataupun secara litigasi dengan mengajukan gugatan melalui pengadilan umum.
\end{abstract}

Kata kunci: Perlindungan Hukum; Itikad Baik; Jual Beli.

Abstract. Buying and selling is a common activity that is carried out in everyday life. The sale and purchase transaction is deemed to have occurred when the parties have reached an agreement on the goods sold and the price offered which is then standardized into an agreement. However, often the making and implementation of agreements does not heed the terms and legal principles contained in the KUHPer which should be used as guidelines both at the time of making and implementing the agreement. One of these cases is contained in Decision Number 15 / pdt.G / 2018 / PN.Sby. This study aims to determine the criteria in determining whether a party has good intentions in carrying out a sale and purchase agreement and legal protection against parties with good intentions. In writing this study using the normative legal method, namely by examining the contents of the decision which is then analyzed by interpretation of the law. Based on the research results, to see that one of the parties has good intentions is in two ways, the first is subjectively or at the time of negotiation and contract preparation and objectively by seeing how he can obey the contents of the contract agreement as long as the agreement is implemented. Legal protection that can be provided is by resolving disputes by making legal suits either through non-litigation through the Consumer Dispute Resolution Agency with all its powers or by litigation by filing a lawsuit through a public court.

Keywords: legal protection; good faith; buying and selling

\section{PENDAHULUAN}

Indonesia merupakan negara hukum sebagaimana yang terdapat dalam konstitusi yang kemudian ditegaskan dalam Pasal 1 Ayat 3 UUD 1945 yang menyatakan bahwa "Negara Indonesia adalah Negara Hukum". Konsekuensi dari ketentuan tersebut adalah pelaksanaan prinsip-prinsip negara hukum yang di antaranya, kepastian hukum, supermasi hukum dan persamaan di hadapan hukum. Prinsip kepastian hukum mendorong dan melindungi setiap orang dalam menjalankan hak dan kewajibannya. Kepastian hukum dibutuhkan dalam kehidupan sehari-hari karena setiap orang tidak luput dari interaksi karena pada dasarnya manusia yang satu dan yang lainnya saling membutuhkan untuk dapat memenuhi kebutuhan hidupnya, oleh karena itu mereka melakukan hubungan yang satu dengan yang lainnya baik berupa yang perbuatan hukum maupun bukan perbuatan hukum. Salah satu bentuk hubungan yang sering dilakukan manusia adalah jual beli yang kemudian melahirkan perjanjian. ${ }^{1}$

Jual beli adalah kegiatan yang umum dilakukan. Hampir semua kegiatan dalam hidup kita dilakukan dengan transaksi jual beli, baik jual beli untuk pemenuhan kebutuhan primer maupun kebutuhan sekunder. Dalam kegiatan jual beli tersebut dapat dilakukan dengan hanya menggunakan lisan dan atau menggunakan tulisan, jual beli tersebut

1 Michael, Gunawan Djajaputra,'Perlindungan Hukum Bagi Pembeli Yang Beritikad Baik (Studi Kasus : Putusan Mahkamah Agung Nomor 1696K/PDT/2016)"Jurnal Hukum Adigama vol 1, No 1, (2018):2. 
dianggap telah terjadi apabila para pihak telah mencapai kesepakatan atas barang yang jual dan harga yang di tawarkan.

Kegiatan jual-beli yang terjadi di dalam masyarakat kerap kali menimbulkan berbagai macam persoalan, salah satu persoalan tersebut berupa pelaksanaan prestasi para pihak. Tidak dilaksanakannya kewajiban salah satu pihak pada akhirnya akan menimbulkan kerugian terhadap pihak yang berhak atas prestasi yang berujung pada terjadinya wanprestasi. Dalam hukum perdata seseorang dianggap melakukan wanprestasi apabila ia tidak memenuhi perikatannya. Berdasarkan hal tersebut perjanjian dibuat sebagai suatu perangkat yang secara khusus mengatur dan melindungi kepentingan parah pihak.

Dalam membuat perjanjian tidak dianjurkan dilakukan secara lisan, karena apabila salah satu pihak melakukan ingkar terhadap apa yang ia perjanjikan dalam perjanjian tersebut pembuktian dipersidangan akan menjadi sulit karena tidak mempunyai alat bukti yang konkret. Hendaknya persetujuan dilakukan secara tertulis sehingga apabila salah satu pihak tidak melakukan kewajibannya dalam persetujuan yang ia perjanjikan maka bukti tertulis tersebut akan memudahkan para pihak dalam hal pembuktian di persidangan.

Namun seringkali dalam pembuatan dan pelaksanaan kontrak perjanjian tidak mengindahkan syarat perjanjian dan asas hukum yang terdapat dalam Kitab Undang-undang Hukum Perdata yang seharusnya dijadikan pedoman, baik pada saat pembuatan perjanjian dan pada saat pelaksanaan perjanjian tersebut sehingga tujuan dalam isi kontrak perjanjian tersebut dapat tercapai dan isi pada kontrak perjanjian tersebut dapat di akui oleh hukum dan dapat dipertanggung jawabkan oleh kedua belah pihak yang membuat perjanjian tersebut.

Salah satu asas dalam perjanjian yang harus dilaksanakan adalah asas itikad baik, hal tersebut sebagaimana yang telah diatur dalam Pasal 1338 Ayat (3) yang mengamanatkan setiap perjanjian harus dilaksanakan dengan itikad baik. Penerapan dari asas itikad baik sendiri bertujuan agar dalam proses jual beli berlangsung lancar dan tidak merugikan para pihak yang sepakat membuat perjanjian jual beli. ${ }^{2}$

Seperti pada kasus dengan putusan nomor 15/pdt.G/2018/pn,sby yang memuat perjanjian jual beli, yakni Agus Simanullang sebagai penggugat dan PT. AMERTA DIRJA PUTRA sebagai tergugat. Kasus ini bermula pembeli bermaksud untuk membeli 2 unit perumahan pada blok CC-1 dan Blok DD-1, dengan kontrak perjanjian yang bernomor 112/ADP/ADM.EKS/SPJBR/10 telah di sepakati oleh kedua belah pihak. Harga masing-masing unit rumah yaitu, pada Blok DD-1 telah disepakati sebesar Rp. 270.446 .350 (dua ratus tujuh puluh juta empat ratus empat puluh enam ribu rupiah) dan Rp. 560.250.000 (lima ratus enam puluh juta dua ratus lima puluh ribu rupiah) untuk unit yang berada pada blok CC-1 yang berdasarkan kesepakatan pembayaran dilakukan dengan cara mencicil dan sebagai wujud kesungguhan pembeli memberikan tanda terima sebesar Rp. 1.500 .000 (satu juta lima ratus ribu rupiah) kepada masing-masing unit.

Namun pada saat pelaksanaan perjanjian jual beli tersebut ternyata pihak penjual tidak melaksanakan perjanjian sesuai dengan isi pada kontrak perjanjian yang telah disepakati, di mana penjual dengan dalih pembeli tidak memenuhi persyaratan untuk melengkapi berkas KPR kepada Bank maka pembeli dianggap telah wanprestasi dan penjual dengan sepihak membatalkan perjanjian dengan ingin mengembalikan angsuran yang telah diberikan. Padahal diketahui penjual menghubungi pembeli untuk mengganti nama di pengajuan KPR Bank agar dapat di ACC oleh Pihak Bank dan anjuran dari penjual disetujui oleh pembeli kemudian Pembeli melengkapi persyaratan untuk perubahan data untuk permohonan KPR di Bank dan kemudian sekitar bulan November 2015 pembeli mendatangi penjual untuk menyerahkan berkas-berkas, namun pembeli mengatakan bahwa untuk pemesanan Rumah di Blok DD 1 dan Blok CC -1 tidak dapat diubah atau diganti kepada siapa-pun dan penjual meminta agar pembelian 2 unit rumah tersebut di bayar cash / tunai dan pembeli diberikan waktu kurang lebih 2 minggu untuk melunasinya;

Pihak pembeli juga telah melakukan kewajibannya membayar uang muka sebesar Rp. 53.989.250,- (Lima Puluh Tiga Juta Sembilan Ratus Delapan Sembilan Dua Ratus Lima Puluh Rupiah) untuk unit Blok DD - 1 dan Blok CC - 1 sebesar Rp.63.860.750,- (Enam Puluh Tiga Juta Delapan Ratus Enam Puluh Tujuh Ratus Lima Puluh Rupiah) dengan total kerugian Materil sebesar Rp. 117.850.000,- (seratus tujuh belah juta delapan ratus lima puluh ribu rupiah).

Selain itu padahal setalah semua uang muka pembelian 2 unit rumah tersebut lunas dari tahun $2012-2015$ namun ke 2 rumah tersebut tidak juga di serahkan kepada pembeli padahal pembeli berniat untuk membayar cicilan pelunasan pembelian 2 unit rumah tersebut. Namun penjual hanya memberikan janji - janji kepada pembeli dan tanpa alasan yang jelas penjual mengatakan proses pengajuan KPR di Bank batal dan meminta agar pembayaran pembelian rumah secara In house (kepada penjual dan / atau pembayaran Cash/Tunai dan pembeli menyanggupi akan tetapi penjual mengatakan bahwa harga sudah berubah bukan harga lama sesuai dengan SPJBR.

Akibat wanprestasi tersebut pihak pembeli merasa dirugikan dan tidak dapat menikmati hak-haknya sebagai pembeli padahal dalam pelaksanaan perjanjian tersebut pihak pembeli telah beritikad baik dengan mentaati semua isi

${ }^{2}$ Andi, Hartiana, "Penerapan Asas Itikad Baik Dalam Perjanjian Jual Beli Online (Studi kasus di kota mataram)", Jurnal Fakultas Hukum Universitas Mataram (2018):8. 
pada kontrak perjanjian nomor 112/ADP/ADM.EKS/SPJBR/10 dan mengikuti setiap prosedur yang diarahkan oleh penjual.

Mengingat Undang-undang Nomor 8 Tahun 1999 Tentang Perlindungan Konsumen memiliki tujuan untuk meningkatkan kesadaran, kemampuan dan kemandirian konsumen dalam melindungi diri, mencegah dari efek negatif penggunaan barang dan atau jasa, meningkatkan pemberdayaan konsumen dalam memilih, menentukan dan menuntut hak sebagai konsumen, serta memberikan kepastian hukum dan keterbukaan informasi. ${ }^{3}$

Berdasarkan hal tersebut, yang menjadi rumusan dalam penulisan artikel ilmiah ini diantaranya adalah sebagai berikut:

1. Bagaimana kriteria untuk menentukan bahwa salah satu pihak telah beritikad baik dalam melaksanakan perjanjian jual beli ?

2. Bagaimana perlindungan hukum bagi pihak yang telah beritikad baik pada perjanjian jual beli?

State of the art diambil dari penelusuran beberapa contoh penelitian terdahulu yang digunakan sebagai panduan dan acuan dalam melakukan penelitian ini, yaitu berupa jurnal antara lain:

Artikel yang ditulis oleh Priyono, Ery Agus yang berjudul,"Peranan Asas Itikad Baik Dalam Kontrak Baku (Upaya Menjaga Keseimbangan bagi Para Pihak)". Pada jurnal Diponegoro Law Review Volume 1, No.1 pada 2017, yang meneliti mengenai peranan asas itikad baik sebagai penyeimbang kepentingan para pihak.

Pembaharuan dalam penelitian ini adalah mencoba untuk melakukan pembahasan mengenai bagaimana kriteria untuk menentukan bahwa salah satu pihak telah beritikad baik dalam melaksanakan perjanjian jual beli dan perlindungan hukum bagi pihak yang telah beritikad baik pada perjanjian jual beli. Mengingat begitu pentingnya asas itikad baik dalam perjanjian guna untuk melindungi kepentingan para maka dirasa perlu untuk membuat artikel ini.

\section{METODE}

Metode penelitian yang digunakan adalah hukum normatif yaitu dengan mengkaji data atau studi yang berasal dari dokumen-dokumen tertulis seperti putusan pengadilan, undang-undang dan jenis penelitian hukum lainnya. Jenis dan sumber data yang diperlukan dalam penelitian ini adalah menggunakan data sekunder antara lain diperoleh dari dokumen-dokumen tertulis seperti dokumen resmi, buku, dan jenis penelitian hukum lainnya. Metode pengumupulan data dilakukan dengan studi dokumen dan studi Pustaka atau Teknik pengumpulan data sekunder. Teknik pengumpulan data dilakukan dengan cara penelitian studi kepustakaan (Library Research), yaitu penelitian yang dilakukan dengan cara menghimpun informasi yang relevan menggunakan topik atau perkara sebagai objek penelitian. Informasi tersebut dapat diperoleh melalui buku-buku, karya ilmiah, tesis, disertasi, dan lain-lain.

Penelitian ini dilakukan dengan cara mengkaji isi Putusan Nomor 15/pdt.G/2018/PN.Sby. Tulisan ini menggunakan pendekatan perundang-undangan (statute apprroach). Yang kemudian dianalisis dengan interpretasi undang-undang. Perundang-undangan yang dimaksud adalah Kitab Undang-undang Hukum Perdata (KUHPerdata) dan Undang-Undang Nomor 8 Tahun 1999 Tentang Perlindungan Konsumen.

\section{HASIL DAN PEMBAHASAN \\ Kriteria Yang Dapat Menggambarkan Bahwa Salah Satu Pihak Telah Beritikad Baik Dalam Perjanjian Jual Beli}

Jual beli menurut Kitab Undang-undang Hukum Perdata adalah sebuah persetujuan dimana apabila salah satu pihak sebagai pemilik barang telah menyerahkan barangnya dan mengikatkan dirinya dengan salah satu pihak lain yang membayar harga sesuai dengan yang dijanjikan dimana salah satu pihak tersebut disebut sebagai pembeli. Perjanjian jual beli dapat dikatakan telah terjadi diantara pihak pembeli dan penjual telah melakukan kesepakatan tentang barang dan harga yang ditawarkan meskipun barang belum diberikan oleh pihak penjual dan pihak pembeli belum membayarkan atas harga yang di sepakati. ${ }^{4}$ Maka dalam hal ini jual beli dapat terjadi begitu saja walaupun persetujuan hanya dilakukan secara lisan bukan secara tertulis namun hal itu telah dikategorikan sebagai jual beli karena para pihak telah bersama-sama melakukan kesepakatan atas barang dan harga yang ditawarkan.

Dalam membuat suatu perjanjian haruslah memenuhi syarat-syarat perjanjian, sehingga kontrak perjanjian tersebut dapat diakui oleh hukum dan sebab akibatnya dapat dipertanggungjawabkan oleh kedua belah pihak yang membuat perjanjian tersebut. Syarat-syarat perjanjian tersebut terdapat dalam Pasal 1320 KUHPer yang berbunyi:

1. Sepakat bagi mereka yang mengikatkan dirinya

2. Cakap dalam membuat suatu perikatan

3. Suatu hal tertentu

\footnotetext{
3 Pengertian Perlindungan Konsumen Tujuan dan Asasnya, https://www.seputarpengetahuan.co.id/2018/06/pengertianperlindungan-konsumen-tujuan-asas-asas.html

${ }^{4}$ Pasal 1457-1458, Buku III,Kitab Undang-undang Hukum Perdata
} 
4. Suatu sebab yang halal. ${ }^{5}$

Tidak hanya syarat-syarat perjanjian saja yang menjadi penting dalam membuat perjanjian, asas hukum juga penting dalam pembuatan perjanjian dan dalam pelaksanaan perjanjian, karena asas hukum adalah pedoman bagaimana suatu perjanjian dapat dijalankan berdasarkan norma dan peraturan perundang-undangan yang berlaku.

Menurut Satjipto Rahardjo, asas hukum dapat diartikan sebagai kebenaran dasar oleh kalangan hukum yang bersangkutan, karena melalui asas hukum itulah akhlak sosial dan pertimbangan sosial dimasukkan kedalam undangundang. Oleh karena itu, asas hukum menjadi sumber hukum kehidupan melalui etika, dan nilai-nilai sosial masyarakat.

Asas hukum adalah landasan yang paling luas bagi lahirnya suatu peraturan hukum, yang berarti bahwa peraturan hukum dapat dikembalikan pada asas-asas tersebut. Asas hukum memiliki fungsi sebagai pedoman dan arahan orientasi bagaimana hukum dapat dijalankan. Asas-asas tersebut juga berguna untuk menerapkan suatu aturan. Ada lima asas penting dalam hukum perjanjian, yaitu;

1. Asas Kebebasan Berkontrak

2. Asas Konsensualisme

3. Asas Pacta Sunt Servanda

4. Asas Itikad Baik

5. Asas Kepribadian. ${ }^{6}$

Asas itikad baik dan kepatutan berasal dari Romawi, yang pada akhirnya dianut oleh civil law, yang dalam perkembangannya juga dianut oleh beberapa negara yang menganut sistem hukum common law. Dalam perkembangannya asas itikad baik tidak lepas dari evolusi hukum kontrak itu sendiri. Yang pada awalnya Hukum Romawi hanya mengenal iudicia stricti iuris, yaitu kontrak yang lahir karena perbuatan hukum (negotium) yang secara ketat dan formal mengacu pada ius civile. Apa bila hakim menghadapi kasus kontrak yang sama seperti itu, makai ia harus memutusnya sesuai dengan hukum. Berikutnya berkembang iudicia bonae fidei yang disebut negotia bonae fidei yang berasal dari ius gentium yang mensyaratkan bahwa kontrak harus dibuat dengan itikad baik. ${ }^{7}$

Dalam Kamus Besar Bahasa Indonesia itikad berarti tekad keyakinan dan kepercayaan yang berkemauan teguh. ${ }^{8}$ Asas itikad baik menegaskan bahwa dalam membuat perjanjian harus didasarkan dengan itikad baik dan kepatutan dengan kata lain bahwa di antara para pihak yang membuat perjanjian harus mengutamakan kejujuran untuk mencapai tujuan bersama. Prinsip itikad baik adalah prinsip yang mendasar dalam jual beli. Karena suatu kontrak atau perjanjian akan berjalan dengan semestinya apabila kedua belah pihak telah beritikad baik untuk memenuhi hak dan kewajiban.

Di Belanda, Pasal 1374 (3) BW Belanda yang menetapkan bahwa perjanjian itu harus dilaksanakan dengan itikad baik. Menurut P.L Werry, kedua belah pihak harus saling jujur dan tidak mengganggu atau mengganggu kepentingan pihak lain. Kemudian itikad baik dibagi menjadi dua jenis itikad baik pra kontrak (Subjektif) dan itikad baik dalam pelaksanaan kontrak (Objektif).

a. Itikad baik dalam arti pra kontrak (subjektif)

Bahwa itikad baik dalam hal ini terletak pada sikap batin seseorang, dalam hukum benda itikad baik biasanya diartikan dengan kejujuran.

b. Itikad baik dalam arti pelaksanaan kontrak (objektif)

Bahwa perjanjian harus dilaksanakan berdasarkan dengan norma-norma kepatutan dan kesusilaan yang berarti bahwa perjanjian dilaksanakan dengan tanpa merugikan salah satu pihak.

Asas itikad baik dalam perkembangannya memiliki beberapa fungsi di antaranya;

1. Penafsiran kontrak harus di dasarkan pada itikad baik

Sistem hukum belanda menerangkan bahwa peran itikad baik pada penafsiran kontrak di bangun oleh pengadilan. Jika kontrak harus ditafsirkan dengan itikad baik maka isi dari kontrak haruslah ditafsirkan secara fair atau patut. Karawang

5 Iman Hayatul, Candra, Wulansari, 2013, Hukum Perikatan, Karawang: Fakultas Hukum Universitas Singaperbangsa

${ }^{6}$ Niru, Anita Sinaga, "Peranan Asas-Asa Hukum Perjanjian Dalam Mewujudkan Tujuan Perjanjian", Binamulia Hukum vol 7, No.2 (2018):117.

${ }^{7}$ Priyono, Ery Agus, "Peranan Asas Itikad Baik Dalam Kontrak Baku (Upaya Menjaga Keseimbangan bagi Para Pihak)" Jurnal Diponegoro Law Review vol 1, No.1 (2017):13.

${ }^{8}$ Kamus Besar Bahasa Indonesia, https://kbbi.web.id/itikad 
2. Penafsiran kontrak ini dapat dilakukan pada kontrak yang sudah jelas ataupun pada kontrak yang belum jelas tergantung dari kehendak para pihak atau suatu keadaan khusus yang relevan untuk menentukan makna yang mereka maksud.

3. Fungsi itikad baik yang menambah

Fungsi ini dapat menambah isi pada perjanjian tertentu dan juga dapat menambah kata-kata ketentuan undangundang mengenai perjanjian itu. Yang dapat diterapkan apabila ada hak dan kewajiban yang timbul diantara para pihak namun hak dan kewajiban tersebut tidak timbul secara tegas dinyatakan dalam kontrak.

4. Fungsi baik membatasi atau meniadakan

Bahwa suatau perjanjian tertentu atau suatu ketentuang undang-undang tertentu dapat dikesampingkan jika pada saat dibuatnya kontrak tersebut keadaan telah berubah, sehingga dalam pelaksanaanya dapat menimbulkan ketidakadilan. Dalam kedaan tersebut kewajiban kontraktual dapat dibatasi bahkan ditiadakan seluruhnya dengan didasarkan pada itikad baik. meliputi: ${ }^{9}$

Berdasarkan pendapat J. M. Van Dunne, para pihak dalam setiap perjanjian akan melalui tiga tahapan, yang

1. Tahap Prakontraktual

2. Tahap Kontraktual

3. Tahap Pascakontraktual.

Apabila tiga tahapan tersebut dikaitkan dengan asas itikad baik maka proses negosiasi dalam tahap awal penyusunan kontrak merupakan tahap prakontraktual. Di mana dalam negosiasi perjanjian para pihak sudah harus beritikad baik dengan mengedepankan kejujuran. ${ }^{10}$ Tahapan prakontraktual merupakan awal pembuka jalan dalam membuat kontrak yang sebenarnya, karena pada tahapan para pihak harus menentukan untuk tetap melanjutkan perjanjian atau tidak. Dalam tahapan ini para pihak tidak dapat menarik diri dengan sepihak apabila telah mencapai tahapan tertentu dalam negosiasi. ${ }^{11}$

Setalah para pihak melalui tahapan prakontraktual kemudian akan dilanjutkan dengan tahapan kontraktual, di mana pada bagian ini para pihak melakukan penyusunan isi kontrak dengan mengacu pada ketentuan Pasal 1320 KUHPerdata. Selain itu dalam perjanjian juga harus memuat unsur-unsur dalam kontra yang meliputi: ${ }^{12}$

1. Unsur esensialia

Unsur esensialia adalah unsur yang harus terdapat di dalam perjanjian, yang memuat mengenai prestasi para pihak. Karena apabila tidak terdapat unsur esesialia dalam perjanjian jual beli maka perjanjian tersebut akan batal demi hukum karena tidak terdapat prestasi yang harus dilakukan dalam hal ini kesepakatan mengenai barang dan harga barang.

2. Unsur Naturalia

Unsur Naturalia adalah unsur yang tidak di atur secara khusus dalam perjanjian tetapi terdapat di dalam UndangUndang. Namun walaupun tidak diatur dalam perjanjian unsur tersebut selalu dianggap ada dan berlaku. Contohnya dalam perjanjian jual beli apabila tidak mengatur mengenai cacat barang maka ketentuan yang berlaku adalah ketentuan KUHPerdata mengenai cacat tersembunyi.

3. Unsur Aksidentalia

Unsur Aksidentalia merupakan unsur yang nanti ada atau akan mengikat para pihak atau disebut sebagai unsur pelengkap. Yang memuat mengenai ketentuan yang dapat diatur secara menyimpang dan berdasarkan kesepakatan para pihak. Contohnya apabila dalam kontrak jual beli, si debitur lalai melakukan angsuran maka akan dikenakan denda sebanyak yang telah disepakati dan apabila lalai melebihi dua bulan maka barang akan ditarik tanpa melalui pengadilan.

Tahapan terakhir yang dilalui oleh para pihak dalam perjanjian adalah tahapan pascakontraktual, yang apabila dikaitan dengan dengan asas itikad baik tahapan ini merupakan obyektif karena berkaitan dengan pelaksaan isi dari pada perjanjian yang telah disepakati. Berdasarkan hal tersebut standar atau tolak ukur untuk melaksanakan kesepakatan dengan itikad baik adalah obyektif. Dalam hukum kontrak, yang dimaksud dengan itikad baik adalah

9 Antarari, Innaka, dkk,’Penerapan Asas Itikad Baik Tahap Prakontraktual Pada Perjanjian Jual Beli Rumah", Jurnal Mimbar Hukum Vol 24, No.3 (2012):507.

${ }^{10}$ Ibid.

${ }^{11}$ Arif, Firmansyah,” Karakteristik Head Of Agreement Menurut Hukum Kontrak Indonesia”, Jurnal Juris-Diction Vol 2, No.3 (Mei 2019):853.

12 I, Gde Prima Hadi Susetnya, dkk, “ Adaptasi Doktrin Promissory Estoppel Dalam Penyelesaian Ganti Rugi Pada Tahap Pra Kontrak Pada Hukum Kontrak Di Indonesia”, Acta Comitas Vol 1, (2018):113.. 
mengacu pada kepatuhan terhadap standar bisnis yang wajar dan adil. Legislator Belanda mengatakan bahwa bertindak sesuai dengan redelijkheid en bilijkheid (reasonableness and equity). ${ }^{13}$

Oleh karenanya apabila suatu perjanjian tidak didasarkan asas perjanjian dalam pembuatannya atau ketika pelaksanaanya maka perjanjian tersebut menjadi tidak seimbang, kemudian terjadilah wanprestasi. Apabila salah satu pihak tidak melakukan sesuatu padahal dalam isi perjanjian dikatakan harus melakukan sesuatu maka ia dapat dikatakan telah melakukan wanprestasi.

\section{Perlindungan Hukum Bagi Pihak Yang Telah Beritikad Baik Pada Perjanjian Jual Beli.}

Hukum sebagai aturan yang mempunyai fungsi untuk mengatur segala kegiatan dalam kehidupan dimasyarakat, dalam menjalankan fungsinya hukum tidak dapat bekerja sendiri melainkan Bersama dengan para penegak hukum lainnya dan senantiasa hidup dan merespon setiap perkembangan yang terjadi dilingkungannya ${ }^{14}$.

Dalam bukunya Rhetorica, Aristoteles menjelaskan bahwa hukum bertujuan untuk memberikan keadilan. Bahwa hukum mempunyai tugas yang sangat suci dan luhur yang memberikan apa yang harus diberikan kepada setiap kasus dengan peraturannya. Hukum juga harus membuat algemene regels (peraturan/ketentuan umum) yang bertujuan untuk memberikan kepastian hukum pada masyarakat. ${ }^{15}$.

Sajipto Raharjo menyebutkan perlindungan hukum adalah sebagai upaya untuk memberikan dan melindungi berbagai kepentingan dalam masyarakat agar setiap kepentingan yang ada di masyarakat tidak saling bertabrakan, sehingga semua masyarakat dapat melakukan kepentingannya dan menikmati semua hak yang diberikan oleh hukum.

Perlindungan hukum terbagi menjadi dua yaitu, perlindungan hukum preventif dan represif. Perlindungan hukum preventif adalah perlindungan untuk mencegah terjadinya sengketa, juga mengarahkan pemerintah untuk bersikap hati-hati dan segala pengambilan keputusan dilakukan dengan diskresi. ${ }^{16}$

Adapun bentuk perlindungan hukum sendiri, yakni:

1. Perlindungan Hukum Preventif.

Perlindungan hukum preventif merupakan perlindungan yang diberikan oleh pemerintah untuk mencegah terjadinya pelanggaran dan sengketa. Hal ini dilakukan melalui pembentukan peraturan perundang-undangan dengan tujuan memberikan rambu-rambu atau batasan dalam melakukan sesuatu tindakan hukum.

2. Perlindungan Hukum Represif.

Perlindungan hukum represif adalah perlindungan hukum terakhir yang merupakan kelanjutan dari pelanggaran terhadap perlindungan hukum preventif, berbentuk penjatuhan hukuman berupa denda, penjara dan hukuman tambahan lainnya.

Salah satu pembentuk perlindungan terdapat dalam kasus wanprestasi jual beli rumah. Di mana pelaku usaha yaitu pihak penjual tidak melakukan prestasinya yaitu, tidak melaksanakan isi perjanjian sebagaimana yang telah disepakati. Untuk menentukan salah satu pihak telah melakukan wanprestasi dapat dilihat pada pasal 1234 KUHPerdata yaitu:

1. Melakukan sesuatu

2. Berbuat sesuatu

3. Tidak berbuat sesuatu.

Maka apabila salah satu pihak tidak melakukan sesuatu padahal dalam isi perjanjian dikatakan harus melakukan sesuatu maka ia dapat dikatakan telah melakukan wanprestasi yang dalam hal ini pelaku usaha atau bisa disebut pihak penjual telah melakukan wanprestasi.

Dalam hal meminta hak-hak yang tidak terpenuhi pihak pembeli dapat menyelesaikan sengketa baik secara litigasi (melalui pengadilan) dan secara non litigasi (diluar pengadilan). Dalam hal pemilihan jalur penyelesaian sengketa para pihak mempunyai hak untuk memilih jalur mana yang dirasa tepat untuk penyelesaian sengketa tersebut, namun penyelesaian sengketa biasanya dilakukan dengan jalur non litigasi (diluar pengadilan) terlebih dahulu, apabila selama proses penyelesaian sengketa secara non litigasi (diluar pengadilan) tidak ada perkembangan

13 Sasmita, Anggit Febriana, "Tinjauan Yuridis Asas Itikad Baik Dalam Pelaksanaan Kontrak Kerjasama Antara Pengusaha Investor (Studi Kasusu Angkringan Jogja Management Jl.Bimosari Tahunan UH 3/253 Yogyakarta 55167)”: 20-21

14 Apriani, Rani,Kurniawati,Grasia, "Perlindungan Hukum Terhadap Wanprestasi Dalam Praktek Bisnis Usaha Kuliner Waralaba Di Karawang, Jurnal Syiar Hukum Jurnal Ilmu Hukum, vol 17, No 1 (2019):16.

${ }^{15}$ Muhammad Reza, Kepastian Hukum, https://www.metrokaltara.com/kepastian-hukum/, (Diakses pada 8 Januari 2021 $10: 15)$

${ }^{16}$ Nola, Febryka Luthvi, "Upaya Perlindungan Hukum Terpadu Bagi Tenaga Kerja Indoensia (TKI)", NEGARA HUKUM ,7,No 1 (2016):40. 
yang memuaskan untuk para pihak, maka selanjutnya dapat ditempuh penyelesaian sengketa secara litigasi (melalui pengadilan) ${ }^{17}$.

Pada umumnya apabila konsumen mengalami kerugian ataupun sengketa, konsumen dapat memilih penyelesaian sengketa tersebut dengan melalui litigasi ataupun non-litigasi. Apabila konsumen memilih menyelesaikan sengketa melalui non litigasi maka sengketa akan di selesaikan oleh Badan Penyelesaian Sengketa Konsumen (BPSK) berdasarkan dengan kemampuan dan kewenangannya. Namun apabila konsumen memilih menyeselaikan sengketa dengan litigasi maka Langkah pertama adalah dengan melakukan somasi terlebih dahulu lalu dilanjutkan dengan gugatan.

Maka upaya yang dapat dilakukan oleh konsumen apabila pelaku usaha telah melakukan wanprestasi, dalam Undang-undang Perlindungan Konsumen dapat diselesaikan oleh Badan Penyelesaian Sengketa Konsumen (BPSK). Badan penyelesaian sengketa konsumen adalah badan yang bertugas untuk menyelesaikan permasalahan yang terjadi antara konsumen dengan pelaku usaha. Badan Penyelesaian Sengketa Konsumen adalah Lembaga peradilan konsumen yang ada di setiap daerah tingkat II Kabupaten dan Kota di seluruh Indonesia. Badan Penyelesaian Sengketa Konsumen bertugas untuk menyelesaikan sengketa antara konsumen dengan pelaku usaha di luar pengadilan umum. Badan Penyelesaian Sengketa Konsumen beranggotakan perwakilan dari aparatur pemerintah. Badan Penyelesaian Sengketa Konsumen mempunyai kewenangan dalam melakukan pemeriksaan atas benar atau tidaknya laporan dan keterangan dari pihak-pihak yang bersengketa, dilakukan dengan melihat atau dengan meminta tanda atau bukti bayar, tagihan atau kuitansi, hasil lab atau bukti-bukti lain. Sifat dari Badan Penyelesaian Sengketa Konsumen sendiri adalah mengikat, dalam hal penyelesaian sengketa konsumen Badan Penyelesaian Sengketa Konsumen melakukannya dengan cara ${ }^{18}$;

1. Penyelesaian sengketa dilakukan dengan cara, mediasi atau arbitrase atau konsiliasi

2. Memberikan konsultasi perlindungan konsumen

3. Melakukan pengawasan terhadap klausa baku

4. Melakukan pelaporan kepada penyidik umum apabila terjadi pelanggaran terhadap peraturan perundang-undangan

5. Pengaduan konsumen diterima baik dengan tertulis maupun lisan

6. Melakukan penelitian dan pemeriksaan terhadap sengketa yang terjadi

7. Melakukan pemanggilan terhadap pelaku usaha apabila diduga telah melakukan pelanggaran

8. Memanggil dan menghadirkan saksi, atau saksi ahli, atau setiap orang yang dianggap mengetahui atas pelanggaran yang terjadi pada Undang-undang Perlindungan Konsumen

9. Meninta bantuan kepada penyidik untuk menghadirkan para pihak yang terlibat dalam sengketa apabila tidak memenuhi panggilan Badan Penyelesaian Sengketa Konsumen.

10.Mendapatkan, atau meneliti surat dan dokumen sebagai alat bukti guna penyelidikan dan pemeriksaan.

11.Memutuskan dan menetapkan ada atau tidaknya kerugian

12.Memberitahukan putusan atas pelanggaran yang terjadi kepada pelaku usaha

13.Menjatuhkan sanksi administrative kepada pelaku usaha bila terbukti telah melanggar ketentuan-ketentuan yang tertuang dalam Undang-undang Perlindungan Konsumen ${ }^{19}$.

Kewenangan Badan Penyelesaian sengketa Konsumen untuk menangani sengketa yang terjadi adalah dengan membentuk majelis yang diharuskan ganjil dan sedikit-dikitnya berjumlah tiga orang, terdiri dari seorang ketua merangkap anggota, seorang wakil ketua merangkap anggota, dan seorang anggota, majelis ini terdiri dari elemen yang mewakili unsur yaitu unsur pemerintahan, unsur konsumen dan juga unsur pelaku usaha yang kemudian dibantu juga oleh panitera dan putusan majelis bersifat final dan mengikat ${ }^{20}$.

Apabila Badan Penyelesaian Sengketa Konsumen tidak bisa menyelesaikan sengketanya, maka langkah selanjutnya yang dapat diambil adalah melalui pengadilan yang mengacu pada ketentuan peradilan umum. Umumnya, proses beracara sengketa perlindungan konsumen di pengadilan dengan melalui gugatan perorangan biasa, gugatan sederhana, class action atau gugatan yang diajukan oleh Lembaga perlindungan konsumen swadaya masyarakat atau

17 Apriani, Rani,Kurniawati,Grasia, ”Perlindungan Hukum Terhadap Wanprestasi Dalam Praktek Bisnis Usaha Kuliner Waralaba Di Karawang, Jurnal Syiar Hukum Jurnal Ilmu Hukum, vol 17, No 1 (2019):16.

${ }^{18}$ Hastuty, Yulia Rakhma, "Perlindungan Hukum Terhadap Konsumen Dalam Jual Beli Rumah Susun Komersial Yang Belum Dibangun" : 1-26

${ }^{19}$ Pasal 52, Bab XI, Undang-undang Nomor 8 Tahun1999 Tentang Perlindungan Konsumen

${ }^{20}$ Hastuty, Yulia Rakhma, "Perlindungan Hukum Terhadap Konsumen Dalam Jual Beli Rumah Susun Komersial Yang Belum Dibangun", Jurnal Universitas Brawijaya (2015):1. 
pemerintah dan instansi terkait. Jenis gugatan tergantung pada siapa yang mengalami kerugian, jumlah orang yang mengalami kerugian, dan besarnya kerugian yang ditimbulkan. ${ }^{21}$

Namun mengenai pilihan penyelesaian sengketa konsumen jual beli rumah baik litigasi maupun secara non litigasi dalam hal ini melalui BPSK merupakan pilihan konsumen yang dirugikan sebagaimana Pasal 23 jo Pasal 45 UUPK. Namun karena sifat putusan BPSK yang dapat diajukan keberatan kepada pengadilan kerap kali konsumen memilih penyelesaian sengketa litagasi. ${ }^{22}$

Seperti pada perjanjian jual beli pada surat nomor 112/ADP/ADM.EKS/SPJBR/10 Pihak pembeli dan penjual yang melakukan jual beli 2 unit perumahan pada blok CC-1 dan Blok DD-1, yang dalam surat nomor 112/ADP/ADM.EKS/SPJBR/10 telah disepakati bahwa pembayaran dilakukan dengan dicicil. Kemudian pihak pembeli melakukan pembelian dua unit rumah di perum Griya Amerta Regency dan masing-masing rumah telah dibayarkan booking fee dengan bukti pembayaran atau nota pembayaran yg diberikan oleh pihak penjual.

Kemudian pembayaran uang muka dilakukan dengan dicicil, sambil mengajukan pengajuan KPR kepada bank BTN, selama pengajuan KPR pihak pembeli terus menanyakan perihal kelanjutannya namun, pihak penjual hanya menyuruh pihak pembeli untuk bersabar karena masih dalam kepengurusan ijin-ijin dan alasan yang selalu berubahubah. Setelah itu pengajuan KPR kepada Bank BTN tidak di setujui karena istri dari pihak pembeli telah mengajukan KPR kepada Bank yang sama. Kemudian pihak penjual menghubungi pihak pembeli untuk mengganti nama pada pangajuan KPR Bank agar dapat disetujui, namun ternyata nama tidak bisa diubah dan pihak penjual meminta pembayaran rumah dilakukan dengan cash.

Setelah uang muka 2 rumah tersebut sudah lunas, namun ke 2 rumah tersebut tidak juga diserahkan kepada pihak pembeli padahal pihak pembeli telah berniat membayar cicilan pelunasan, namun pihak penjual hanya memberikan janji-janji tanpa alasan yang jelas. Padahal dengan telah beritikad baik pihak pembeli menyelesaikan pelunasan pembayaran rumahnya dengan cash namun pihak penjual tidak menanggapi.

Pada dasarnya perjanjian jual beli bertujuan untuk memindahkan suatu hak milik atas suatu barang yang diperjual belikan karena dalam jual beli pihak penjual wajib menyerahkan barang yang dijualnya itu

kepada pembeli, sedangkan pihak pembeli memiliki kewajiban untuk membayar harga atas barang tersebut kepada pihak penjual. Sehingga apabila salah satu pihak tidak melakukan kewajibannya tindakan tersebut merupakan wanprestasi.

Bahwa atas wanprestasi tersebut mengakibatkan konsumen mengalami kerugian materil yaitu uang pembayaran uang muka atas 2 unit rumah yang telah dilunasi, tidak menikmati manfaat maupun memiliki 2 unit rumah tersebut dikarenakan janji-janji dan alasan-alasan yang tidak jelas sehingga konsumen mengalami kerugian materil dan imateril. Padahal pihak pembeli atau konsumen telah sukarela dengan beritikad baik mau melunasi sisa pembayaran 2 unit rumah tersebut sebagaimana yang tertuang dalam SPJBR (Surat Perjanjian Jual Beli Rumah).

Dalam hal ini sebagaimana standar asas itikad baik yang menjadi pedoman dalam perjanjian, Agus Simanullang telah melaksanakan perjanjiannya berdasarkan itikad baik yang diantaranya:

1. Bahwa Tindakan yang dilakukan oleh pihak pembeli telah beritikad baik karena pihak pembeli selalu bersifat kooperatif Ketika pihak penjual meminta banyak kelengkapan berkas dalam proses pengajuan KPR kepada Bank BTN.

2. Bahwa Tindakan yang dilakukan oleh pihak pembeli telah beritikad baik dengan telah mecicil uang muka sebagai mana isi dari SPJBR yang telah disepakati.

3. Bahwa Tindakan yang dilakukan oleh pihak pembeli telah beritikad baik dengan mau melunasi pebayaran dua unit rumah secara cash/ tunai.

Salah satu bentuk perlindungan hukum terhadap asas itikad baik yaitu melakukan gugatan dengan meminta ganti rugi atau pelaksaan terhadap prestasi. Dalam kasus ini pihak pembeli meminta kepada majelis hakim untuk memerintahkan kepada penjual menerima sisa pembayaran pelunasan unit sebagaimana SPJBR yang telah disepakati di awal saat. Karena dalih perubahan harga yang dinyatakan oleh pihak penjual bertentangan dengan Pasal 18 UU no. 8 Tahun 1999 Tentang Perlindungan Konsumen Ayat (1) a yang berbunyi :" menyatakan pengalihan tanggung jawab pelaku usaha" jo Ayat (1) g yang berbunyi : "menyatakan tunduknya konsumen kepada peraturan yang berupa aturan baru, tambahan, lanjutan yang dibuat sepihak oleh pelaku usaha dalam masa konsumen memanfaatkan jasa yang diberinya". Ayat (2) yang berbunyi "Pelaku usaha dilarang mencantumkan klausula baku yang terletak atau bentuknya sulit terlihat atau tidak dapat dibaca secara jelas atau yang pengungkapannya sulit dimengerti”. Ayat (3)

\footnotetext{
21 Chrissie Margareta, Hasyry Agustin, "Penyelesaian Sengketa Perlindungan Konsumen" https://bplawyers.co.id/2020/01/29/penyelesaian-sengketa-perlindungan-konsumen/ (2010): 143 .

${ }^{22} \mathrm{H}$, Muksibah, “Analisis Mengenai Cara Penyelesaian Sengketa Konsumen” INOVATIF jurnal Ilmu Hukum Vol 2, No.4,
} 
yang berbunyi "Setiap ) Setiap klausula baku yang telah ditetapkan oleh pelaku usaha pada dokumen atau perjanjian yang memenuhi ketentuan sebagaimana dimaksud pada ayat (1) dan ayat (2) dinyatakan batal demi hukum.

Pada putusan akhirnya majelis hakim memberikan putusan bahwa penjual dalam hal ini tergugat telah melakukan wanprestasi, karena berdasarkan fakta persidangan majelis hakim telah mengakui dan sependapat bahwa pembeli telah beritikad baik dengan mengumpulkan berkas-berkas persyaratan pengajuan KPR ke Bank BTN namun penjual tidak meneruskannya ke Bank BTN dengan alasan yang dibuat-buat seperti tidak pernah mengumpulkan berkas-berkas pengajuan KPR BTN dan juga mengatakan Bank BTN tidak bisa memproses permohonan KPR karena istri penjual telah memiliki KPR BTN sebelumnya. Selain itu berdasarkan pertimbangan di atas, pembeli juga telah membayar lunas uang booking fee, melunasi pembayaran uang muka dan meminta untuk melakukan pelunasan secara tunai namun pihak penjual menolak dan ingin mengembalikan uang muka yang telah disetorkan dengan dalih harga unit telah naik dan tidak sesuai dengan SPJBR yang telah disepakati sebelumnya. Perbuatan tersebut bertentang dengan Pasal 1338 KUH Perdata yang menyatakan: "Semua Perjanjian yang dibuat secara sah berlaku sebagai Undang-Undang bagi mereka yang membuatnya. Suatu perjanjian tidak dapat ditarik kembali selain dengan sepakat kedua belah pihak, atau karena alasan-alasan yang oleh Undang- Undang dinyatakan cukup untuk itu. Suatu perjanjian harus dilaksanakan dengan itikat baik", Sehingga dengan alasan tersebut pembelian rumah Blok CC-1 dan Blok DD-1 terletak di Perumahan Griya Amerta Regency Jalan Medayu Utara Gg.31 C Surabaya sampai saat ini belum bisa terealisasi dan oleh karenanya perbuatan penjual dapat dikategorikan Wanprestasi. Dengan demikian penjual diperintahkan untuk menerima pelunasan pembelian rumah dari Penjual sebagaimana Surat Perjanjian Jual Beli Rumah (SPJBR) tertanggal 25 April 2012 setelah dipotong uang muka yang telah dibayarkan pembeli kepada penjual.

\section{SIMPULAN}

1. Untuk menggambarkan kriteria bahwa partisipan telah beritikad baik adalah dengan melihat bahwa salah satu pihak telah beritikad baik adalah dengan dua cara yang pertama secara subyektif atau pada saat negosiasi dan penyusunan kontrak dan obyektif dengan melihat bagaimana ia dapat taat pada isi kontrak perjanjian selama perjanjian dilaksanakan.

2. Bentuk perlindungan terhadap konsumen pada putusan nomor 15/pdt.G/2018/PN.Sby dengan Surat Perjanjian Jual Beli Rumah (SPJBR) Nomor 112/ADP/ADM.EKS/SPJBR/10 yang mana konsumen telah melakukan kewajibannya dengan tetap beritikad baik dan bahwa pelaku usaha tidak melaksanakan isi perjanjian dengan tidak beritikad baik dan dinyatakan telah melakukan ingkar janji atau wanprestasi. Maka sebagaimana Pasal 19 Undangundang Nomor 8 Tahun 1999 tentang Perlindungan Konsumen, pihak penjual selaku pelaku usaha bertanggung jawab atas hak yang seharusnya diberikan kepada pihak pembeli sebagai konsumen, yang berupa hak ganti rugi uang atau pergantian barang dan atau jasa yang sesuai dengan peraturan yang berlaku atas pembelian 2 unit rumah ataupun menerima pembayaran sisa pelunasan 2 unit rumah yang sebagaimana telah disepakati dalam isi perjanjian SPJBR. Upaya hukum yang dapat dilakukan oleh pihak pembeli sebagai konsumen adalah dengan melakukan penyelesaian sengketa melalui Badan Penyelesaian Sengketa Konsumen (BPSK) dengan segala kewenangannya ataupun dengan mengajukan gugatan melalui pengadilan yang mengacu pada ketentuan peradilan umum.

\section{DAFTAR PUSTAKA}

\section{Buku}

Iman Hayatul, Candra, Wulansari, 2013, Hukum Perikatan, Karawang: Fakultas Hukum Universitas Singaperbangsa Karawang.

\section{Jurnal}

Firmansyah ,Arif,” Karakteristik Head Of Agreement Menurut Hukum Kontrak Indonesia”, Jurnal Juris-Diction Vol 2, No.3 (Mei 2019):853.

Hartiana, Andi, "Penerapan Asas Itikad Baik Dalam Perjanjian Jual Beli Online (Studi kasus di kota mataram)", Jurnal Fakultas Hukum Universitas Mataram (2018):8.

Hastuty, Yulia Rakhma, "Perlindungan Hukum Terhadap Konsumen Dalam Jual Beli Rumah Susun Komersial Yang Belum Dibangun", Jurnal Universitas Brawijaya (2015):1.

Innaka, Antarari, dkk,"Penerapan Asas Itikad Baik Tahap Prakontraktual Pada Perjanjian Jual Beli Rumah", Jurnal Mimbar Hukum Vol 24, No.3 (2012):507.

Kurniawati, Apriani,Rani ,Grasia, "Perlindungan Hukum Terhadap Wanprestasi Dalam Praktek Bisnis Usaha Kuliner Waralaba Di Karawang, Jurnal Syiar Hukum Jurnal Ilmu Hukum, vol 17, No 1 (2019):16.

Luthvi ,Nola Febryka, "Upaya Perlindungan Hukum Terpadu Bagi Tenaga Kerja Indoensia (TKI)", NEGARA HUKUM ,7,No 1 (2016):40. 
Michael \& Gunawan Djajaputra,"Perlindungan Hukum Bagi Pembeli Yang Beritikad Baik (Studi Kasus : Putusan Mahkamah Agung Nomor 1696K/PDT/2016)"Jurnal Hukum Adigama vol 1, No 1, (2018):2.

Muksibah, H, "Analisis Mengenai Cara Penyelesaian Sengketa Konsumen" INOVATIF jurnal Ilmu Hukum Vol 2, No.4, (2010):143.

Priyono, Ery Agus, "Peranan Asas Itikad Baik Dalam Kontrak Baku (Upaya Menjaga Keseimbangan bagi Para Pihak)" Jurnal Diponegoro Law Review vol 1, No.1 (2017):13.

Sinaga,Niru Anita, "Peranan Asas-Asa Hukum Perjanjian Dalam Mewujudkan Tujuan Perjanjian", Binamulia Hukum vol 7, No.2 (2018):117.

Susetnya,I Gde Prima Hadi, dkk, “ Adaptasi Doktrin Promissory Estoppel Dalam Penyelesaian Ganti Rugi Pada Tahap Pra Kontrak Pada Hukum Kontrak Di Indonesia”, Acta Comitas Vol 1, (2018):113.

\section{Skripsi}

Sasmita, Anggit Febriana, "Tinjauan Yuridis Asas Itikad Baik Dalam Pelaksanaan Kontrak Kerjasama Antara Pengusaha Investor (Studi Kasus Angkringan Jogja Management Jl.Bimosari Tahunan UH 3/253 Yogyakarta 55167)”, Skripsi Ilmu Hukum, Program Strata Satu Ilmu Hukum. Yogyakarta : UIN Sunan Kalijaga, 2016. Dipublikasikan.

\section{Peraturan Perundang-undangan}

Kitab Undang-undang Hukum Perdata.

Undang-undang Nomor 8 Tahun 1999 Tentang Perlindungan Konsumen.

\section{Putusan}

Putusan Pengadilan Negeri Surabaya Nomor:15/pdt.G/2018/pn,sby.

\section{Website}

Chrissie Margareta, Hasyry Agustin, "Penyelesaian Sengketa Perlindungan Konsumen" https://bplawyers.co.id/2020/01/29/penyelesaian-sengketa-perlindungan-konsumen/

Muhammad Reza, Kepastian Hukum, https://www.metrokaltara.com/kepastian-hukum/, (Diakses pada 8 Januari 2021 10:15).

Kamus Besar Bahasa Indonesia, https://kbbi.web.id/itikad

Pengertian Perlindungan Konsumen Tujuan dan Asasnya, https://www.seputarpengetahuan.co.id/2018/06/pengertianperlindungan-konsumen-tujuan-asas-asas.html. 